\title{
Transcriptomic analysis of the harvested endothelial cells in a swine model of mechanical thrombectomy
}

\author{
Nasren Jaff ${ }^{1} \cdot$ Rikard Grankvist $^{1} \cdot$ Lars Muhl $^{3} \cdot$ Arvin Chireh $^{1} \cdot$ Mikael Sandell $^{1} \cdot$ Stefan Jonsson ${ }^{1,4} \cdot$ Fabian Arnberg $^{2}$. \\ Ulf Eriksson $^{3}$ - Staffan Holmin ${ }^{1,2}$
}

Received: 19 February 2018 / Accepted: 4 May 2018 / Published online: 14 May 2018

(C) The Author(s) 2018

\begin{abstract}
Purpose In mechanical thrombectomy (MT) for ischemic stroke, endothelial cells (ECs) from intracranial blood vessels adhere to the stent retriever device and can be harvested. However, understanding the molecular biology and the role of the endothelium in different pathological conditions remains insufficient. The purpose of the study was to characterize and analyze the molecular aspect of harvested ECs using cell culture and transcriptomic techniques in an MT swine model relevant to clinical ischemic stroke.

Methods In swine, preformed thrombi were injected into the external carotid and subclavian arteries to occlude their branches. MT was performed according to clinical routine. The stent retriever device and thrombus were treated with cell dissociation buffer. The resulting cell suspension was analyzed by immunohistochemistry and was cultured. Cultured cells were analyzed using single-cell RNA sequencing (scRNA-seq) after fluorescence-activated cell sorting (FACS).

Results A total number of 37 samples were obtained containing CD31-positive cells. Cell culture was successful in $90 \%$ of samples, and the cells expressed multiple typical EC protein markers. Eighty-nine percent of the sorted cells yielded high-quality transcriptomes, and single-cell transcriptomes from cultured cells showed that they expressed typical endothelial gene patterns. Gene expression analysis of ECs from an occluded artery did not show distinctive clustering into subtypes.

Conclusion ECs harvested during MT can be cultured and analyzed using single-cell transcriptomic techniques. This analysis can be implemented in clinical practice to study the EC gene expression of comorbidities, such as hypertension, diabetes mellitus, and metabolic syndrome, in patients suffering from acute ischemic stroke.
\end{abstract}

Keywords Endothelial cells · Transcriptomic analysis · Thrombectomy $\cdot$ Cell culture

$\mathrm{NJ}$ and RG are joint first authors and contributed equally to this study.

Nasren Jaff

nasren.jaff@ki.se

Staffan Holmin

staffan.holmin@ki.se

1 Department of Clinical Neuroscience, Karolinska Institutet, SE-171 76 Stockholm, Sweden

2 Department of Neuroradiology, Karolinska University Hospital, Solna, SE-171 76 Stockholm, Sweden

3 Department of Medical Biochemistry and Biophysics (MBB), Karolinska Institutet, Stockholm, Sweden

4 Department of Materials Science, Royal Institute of Technology, Stockholm, Sweden

$\begin{array}{ll}\text { Abbreviations } \\ \text { MT } & \text { Mechanical thrombectomy } \\ \text { scRNA-seq } & \text { Single-cell RNA sequencing } \\ \text { EC } & \text { Endothelial cell } \\ \text { FACS } & \text { Fluorescence-activated cell sorting } \\ \text { AIS } & \text { Acute ischemic stroke } \\ \text { ECA } & \text { External carotid artery } \\ \text { SCA } & \text { Subclavian artery } \\ \text { PBS } & \text { Phosphate-buffered saline } \\ \text { PAF } & \text { Paraformaldehyde } \\ \text { PCA } & \text { Principal component analysis } \\ \text { LOM } & \text { Light optical microscopy } \\ \text { SEM } & \text { Scanning electron microscopy }\end{array}$




\section{Introduction}

Endothelial cells (ECs) play important roles in many aspects of vascular biology and are thereby involved in the pathophysiological processes of several diseases. In addition to its role as a selective permeability barrier, the ECs are unique multifunctional cells with critical metabolic and synthetic functions [1]. Impaired endothelial function may cause thrombosis and altered glucose and fatty acid transport, which is seen in patients with ischemic heart disease, diabetes, hypertension, and hypercholesterolemia [1-6]. Many of these processes contribute to the pathology of ischemic stroke. Great importance has been suggested for ECs in the activation and propagation of vascular diseases [7].

The advent of mechanical thrombectomy to treat acute ischemic stroke (AIS) [8-12] has enabled unprecedented access to thrombotic material [13-15]. Recently, an adapted new method of harvesting EC biopsy in AIS was demonstrated [16]. We hypothesized that applicability of this protocol for research would benefit from a molecular biology analysis with next-generation sequencing transcriptomics. To maximize the yield of gene expression information from the analyzed cells, we aimed to use single-cell RNA-seq (scRNA-seq) to enable comprehensive transcriptomic analysis. This study presents an effective method for collecting endothelial cells in a swine model of MT using standard clinical devices, culturing them, and subsequently performing single-cell RNA-seq.

\section{Materials and methods}

\section{Animal preparation}

All procedures were conducted according to the Karolinska Institute guidelines for experiments on large animals and were approved by the ethics committee (Norra Stockholms Djurförsöksetiska nämnd, N87/15 and N162/16). Fourteen female Yorkshire-Swedish farm swine ranging from 30 to $35 \mathrm{~kg}$ were used in this study. The procedures were conducted with the swine under general anesthesia by sodium pentobarbital and mechanical ventilation. The animals were euthanized after the experiments.

\section{Thrombus preparation, angiography, and thrombus injection}

We prepared the blood clot for a selective thromboembolization by mixing swine whole blood with a commercial hemostasis agent containing human fibrinogen, factor VIII, human thrombin, calcium chloride, and synthetic aprotinin (TISSEEL, Baxter, IL, USA). The mixture was observed until adequate clot formation had occurred, and elongated thrombi were prepared using scalpel dissection.
A 6F guiding catheter (Cordis, CA, USA) sheath was inserted into the right common femoral artery and continuously flushed with saline. External carotid artery angiography was performed. For selective thromboembolization, the preformed thrombus was injected into a $6 \mathrm{~F}$ guide catheter with the tip placed in the external carotid artery or the subclavian artery. After connecting the silicone tube containing a prepared thrombus into the guide catheter, we injected $(20 \mathrm{ml})$ of saline into the tube to force the thrombus into the catheter. After an angiogram had been obtained to document the occlusion, the guide catheter was retrieved. To simulate the clinical situation in ischemic stroke, the occlusion was maintained at durations $0,5,3$, or $6 \mathrm{~h}$ before thrombectomy was performed.

\section{Harvesting and isolation of cells}

MT was carried out via standard femoral access by using a $6 \mathrm{~F}$ Envoy guiding catheter (Cordis, USA). The catheter was navigated under fluoroscopy guidance to the external carotid artery (ECA) and subclavian artery (SCA) territories. A microcatheter (Prowler Select Plus, Cordis, USA) was navigated to arterial branches, and once in the right position in arteries with inner lumen diameter of $2-4 \mathrm{~mm}$, the Solitaire $6 \times 30 \mathrm{~mm}$ device (Covidien-Medtronic, Ireland) was used as in clinical practice, including leaving the device for $5 \mathrm{~min}$ to expand before retrieval. The device was resheathed into the microcatheter until the beginning of the thrombus before retraction of the whole system. During retrieval, aspiration through the guide catheter was performed according to clinical routine. Directly after removing the device from the guide catheter lumen, the device was immersed and cleaned in dissociation buffer $(0.5 \% \mathrm{BSA}, 100 \mu \mathrm{g} / \mathrm{l}$ heparin, $2 \mathrm{mM}$ EDTA in PBS), to detach possible EC from the device. Using the same device, five attempts were made in different vessels. Each successful attempt resulted in one sample.

\section{Sample handling and preparation procedure}

The samples were centrifuged at $300 g$, the supernatant was removed, and then erythrocyte-lysing buffer was added and the samples were centrifuged again at $300 \mathrm{~g}$. Positive control samples were obtained from swine $(n=2)$, by mechanically scratching the endothelial lining of a surgically dissected artery. The control cells were processed in the same way as described above.

\section{Cell culture}

The tubes were incubated for $5 \mathrm{~min}$ on ice with agitation of tubes once every minute. Five milliliters of PBS was added to each tube and centrifuged for $7 \mathrm{~min}$ at $300 \mathrm{~g}$. The supernatant was discarded and $3 \mathrm{ml}$ of culture medium was added. The 
primary EC cells were cultured using gelatin-coated cell culture plates, $1 \% w / v$ in PBS (Sigma-Aldrich, Schnelldorf, Germany) and endothelial cell growth medium microvascular 2 (EGMV2) (PromoCell, Germany). The culture plates contained growth supplements, $10 \mathrm{U} / \mathrm{ml}$ penicillin, $10 \mu \mathrm{g} / \mathrm{ml}$ streptomycin, and $25 \mu \mathrm{g} / \mathrm{ml}$ amphotericin B (Thermo Fisher Scientific Inc., CA, USA). Two to three days after initial culture, the remaining thrombus and nonadhered cells were washed away with EGMV2 medium. Thereafter, the medium was replaced at intervals of 3 to 4 days, and the cells were passaged when near confluence, using $0.05 \%$ trypsin/EDTA (Thermo Fisher Scientific, CA, USA).

\section{Immunohistochemistry}

Primary isolated cells were cultured on gelatin-coated glass coverslips in 6-well cell culture plates, in EGMV2. Cells were fixed with ice-cold $4 \%$ paraformaldehyde (PFA) in PBS for $10 \mathrm{~min}$ at room temperature (RT). After fixation, cells were blocked with serum-free protein blocking solution (DAKO, Glostrup, Denmark), supplemented with 0.2\% Triton X-100 (Sigma-Aldrich) for $>1 \mathrm{~h}$ at RT. Thereafter, cells were sequentially incubated with primary mouse anti-pig-CD31 dil. 1:100 (AbD Serotec, Germany), rabbit anti-vWF dil. 1:200 (DAKO), and goat anti-VE-cadherin dil. 1:300 (Santa Cruz Biotechnology Inc.) for $24 \mathrm{~h}$ at $4{ }^{\circ} \mathrm{C}$. The cells were rinsed in PBS and subsequently incubated with species-specific secondary antibodies diluted in PBS: Alexa Fluor 488 donkey anti-mouse, Alexa Fluor 555 donkey anti-rabbit, Alexa Fluor 647 donkey anti-goat, all dil. 1:500 (Molecular Probes/ Invitrogen, Germany), and $\mathrm{Cy} 3$ goat anti-mouse (dil. 1:1000, Jackson Immunoresearch, Baltimore, USA). Cells were mounted with ProLong Gold mounting medium containing DAPI (Molecular Probes, CA, USA). Evaluation of the staining and image capture of immunofluorescence micrographs was carried out by using an upright laser scanning, confocal microscope (LSM 700, Carl Zeiss GmbH, Göttingen, Germany).

\section{Single-cell isolation by FACS and cDNA library preparation}

To perform single-cell scRNA-seq, we sorted individual cultured EC onto a 384-well plate preloaded with lysis buffer using fluorescence-activated cell sorting (FACS). A set of cultured endothelial cells from MT and a surgically excised control vessel was prepared for this purpose. The cells were first centrifuged and resuspended in FACS buffer $(1 \times$ PBS, $4 \mathrm{ml}$ of $0.5 \mathrm{M}$ EDTA and $5 \mathrm{~g}$ of BSA). The cells were incubated with an antibody cocktail (CD31, CD146, DAPI) for $30 \mathrm{~min}$ at $4{ }^{\circ} \mathrm{C}$, washed with FACS buffer, and resuspended in $500 \mu \mathrm{l}$ FACS buffer for single-cell sorting. The cells were sorted with the BD FACSJazz cell sorter (BD Biosciences, Franklin
Lakes, NJ, USA). Single cells were sorted one per well onto a 384-well plate prepared with lysis buffer. After sorting, the plates were immediately stored at $-80{ }^{\circ} \mathrm{C}$ and processed for sequencing at a later stage.

scRNA-seq was performed according to the Smart-seq2 protocol [17]. The Illumina HiSeq system (Illumina, San Diego, CA, USA) was used to sequence with a read length of $1 \times 50$ base pairs (single-read).

\section{Data processing and analysis}

Sequencing data was analyzed using an established workflow [18]. Reads were mapped to the reference genome Sscrofa10.2. Quality control was performed before and after mapping, with FastQC version 0.11.5 and QualiMap version 2.2 , respectively. Gene expression values were normalized and expressed as $\log _{2}$ counts per million (CPM). Highly variable genes were selected for principal component analysis (PCA) and unsupervised hierarchical clustering. Cell cycledependent effects were mitigated by using ccRemover [19]. DESeq2 package from Bioconductor for $\mathrm{R}$ (version 3.4, https://bioconductor.org/packages/release/bioc/html/DESeq2. $\mathrm{html}$ ) was used for differential expression analysis on a subset of genes related to EC physiology. For the differential expression analysis, an absolute $\log _{2}$ fold change threshold of $\geq 1$ was used as threshold.

\section{Scanning electron microscopy of stent retriever device}

In order to detect any corrosion attacks on the stent by the dissociation buffer, we investigated the Solitaire stent retriever (Covidien-Medtronic, Ireland) in a light optical microscopy (LOM). The detachment/attachment zone was studied by scanning electron microscopy (SEM), before and after soaking in a dissociated buffer at room temperature. The chemical compositions of the detachment/attachment zone and its surroundings were determined by energy-dispersive $\mathrm{X}$-ray spectroscopy in the SEM. In addition, the chemical compositions of precipitates after soaking were analyzed.

\section{Results}

\section{Mechanical thrombectomy and endothelial cell harvesting}

The procedure was carried out in 14 swine, and the retrievals were effective in all target vessels. The devices were successfully navigated to different branches within the external carotid artery and subclavian artery territory without technical problems (Fig. 1). We were able to harvest viable cells from both occluded and nonoccluded arteries. 


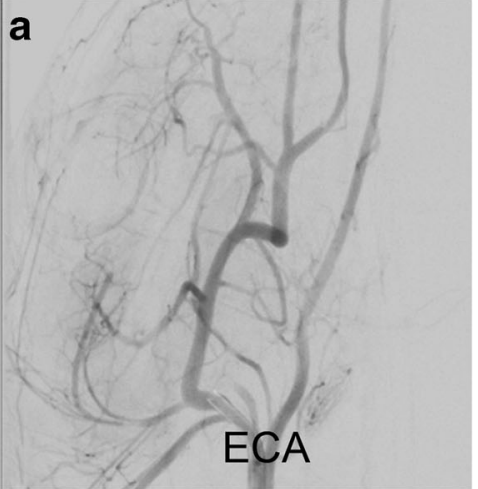

Fig. 1 Anteroposterior angiographies of mechanical thrombectomy procedure. a Catheter tip in the right external carotid artery (ECA) before thrombus injection, showing patent circulation. b After a thrombus injection, a large and a smaller segments are occluded

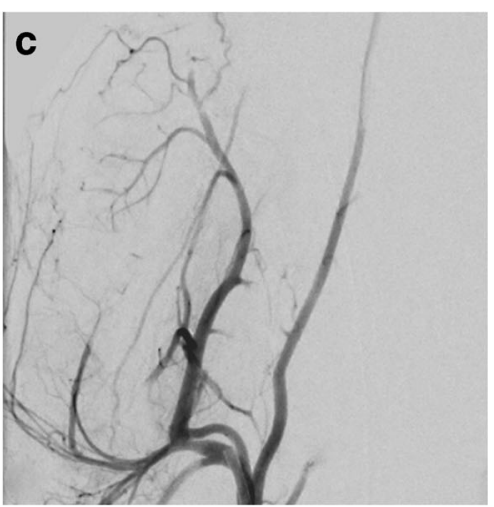

(arrows). c After two passes of mechanical thrombectomy of the occluded segments using a stent retriever device, the smaller segment and the base of the larger segment are again patent. More distal occlusions to the large segment remain

\section{Expansion and proliferation of endothelial cells from mechanical thrombectomy}

We next analyzed whether we could isolate enough viable endothelial cells from MT to expand the cells in culture. Samples $(n=37)$ from the 14 swine were successfully isolated and cultured. In $80 \%$ of the samples, the cells showed excellent growth capacity and could be passaged for up to ten times. Endothelial cell identities were verified by immunohistochemistry. The cells showed CD31, vWF, and VE-cadherin immunoreactivity (Fig. 2a-c). Subsets of cells also showed double-positive staining for $\mathrm{vWF}$ and $\mathrm{CD} 31$ and were considered true phenotypic ECs (Fig. 2d).
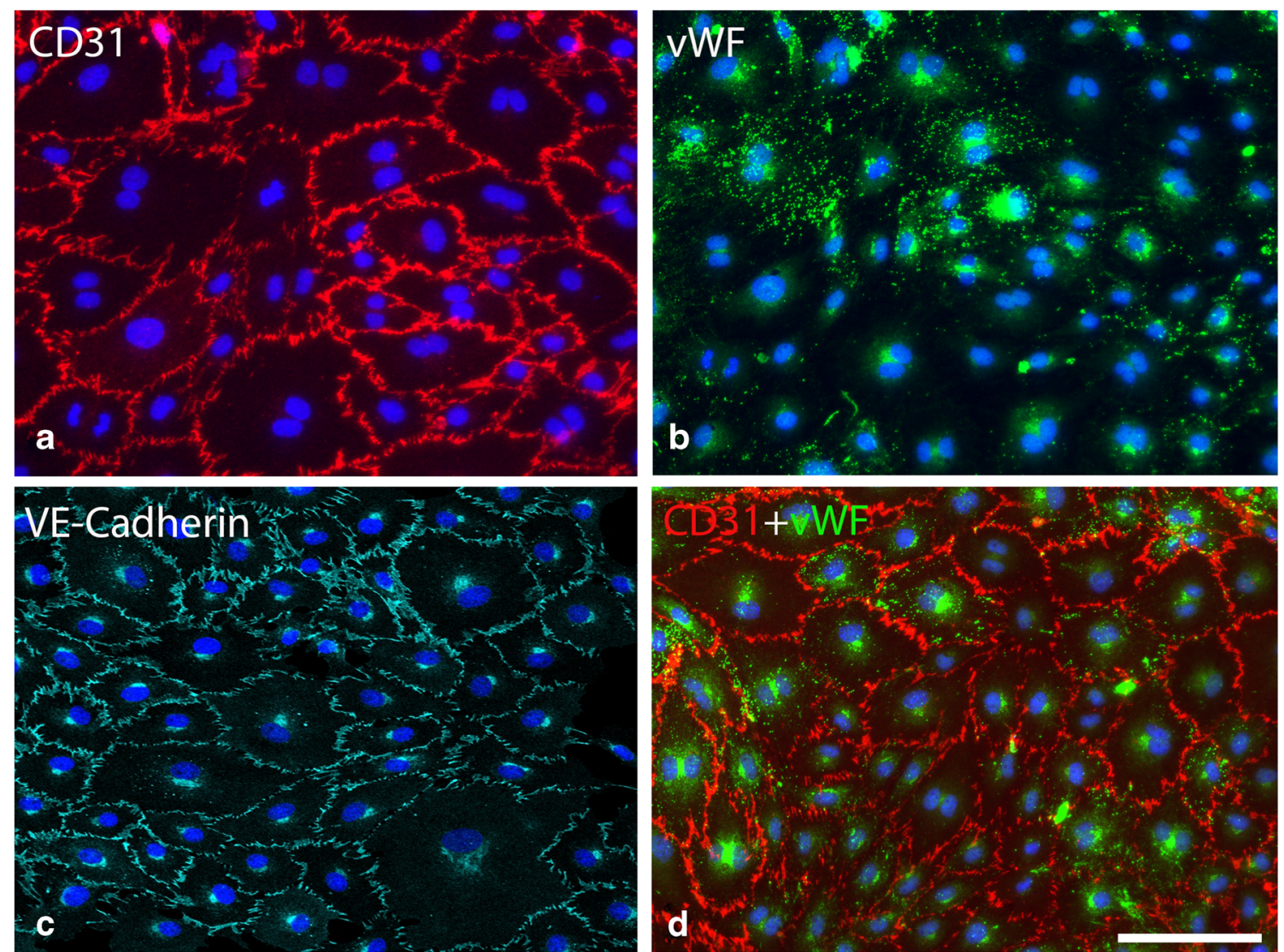

Fig. 2 Immunohistochemistry staining of endothelial cells from cell culture. Endothelial cells revealed by positive CD31 membrane staining (a), vWF cytosol staining (b), VE-cadherin staining $(\mathbf{c})$, and positive CD31 membrane staining and vWF cytosol staining $(\mathbf{d})$. Scale bars $=100 \mu \mathrm{m}$ 


\section{Single-cell RNA sequencing of cultured endothelial cells}

To analyze the functional heterogeneity and to identify the different phenotypes of ECs, we used single-cell RNA-seq on a subset of cultured cells from cells obtained during the MT procedure. A total of 384 ECs were collected by FACS, out of which 345 (90\%) showed high-quality metrics (Fig. 3). Thirty-nine cells were excluded for failing one or more of the following quality criteria: limited sequence depth $(n=33)$, few expressed genes $(n=4)$, too large proportion of mitochondrial genes $(n=9)$, and too large proportion of ERCC sequences $(n=8)$. The cutoff level for each of the quality metrics was $\geq 3$ median absolute deviations. One hundred seventy-five cells of the control samples (91\%) and 170 cells of the MT samples (89\%) were selected for further analysis. Of the 25,414 annotated genes in pig genome, 10,695 genes had an average count of more than $0.5 \log _{2}$ CPM in the highquality samples. Three thousand two hundred sixty-four genes had a significant variance $(p<0.05)$ and an estimated biological variance larger than 0.5 . The results showed high sequencing quality in cells both from control arteries not containing thrombus and those containing thrombus (Fig. 3b). Genes with known upregulation or downregulation in endothelial cells, such as PECAM (CD31), MCAM (CD146), CD34, and vWF, were selected for targeted analysis. The pattern was generally consistent with typical EC expression in both groups. None of the genes were significantly different between the groups using adjusted $p<0.05$ (false discovery rate $=0.1)$ and absolute $\log _{2}$ fold change $>1$ as criteria (Fig. 3c). After controlling for cell cycle, principal component analysis (PCA) and heatmaps for highly variable genes (HVG) did not show any distinct clustering within or between thrombectomy and control samples (Fig. 4 and Fig. 5).

\section{Structural analysis of stent retriever device}

To evaluate the safety of the sampling protocol in a potential clinical application with repeated MT passages involving dissociation buffer, we examined the Solitaire stent retriever (Covidien-Medtronic, Ireland) after the procedure for signs of damage. Visual inspection showed no apparent structural damage even after multiple uses. Further analysis by in vitro exposition of the stent to the cell dissociation buffer and subsequent LOM and SEM showed no structural damage and no signs of corrosion attack or other surface effects on the device other than some saline precipitation (data not shown).

\section{Discussion}

Endothelial tissue availability has been a major constraint when investigating the cellular mechanism of vascular diseases or diseases affected by vascular dysfunction. The critical step in bridging the gap between clinical and basic science is a suitable and safe method to sample ECs and to develop a protocol that enables genetic transcription analysis. In this study, we used a swine model to characterize the molecular biology of the ECs harvested during MT. To achieve high-quality transcriptomes, we needed an intermediate step of cell culture. We demonstrate that it is possible to, by using the routine MT protocol, sample, culture the cells and, then analyze the gene expression in regional cultured ECs using transcriptomics.

Cell culture allows direct characterization of endothelial phenotype and is useful for understanding the interaction between ECs and various mediators; however, it is often criticized due to the uncertain relevance of results to the in vivo situation in humans [20]. The culture step is known to cause changes in gene expression, especially if many passages are performed before analysis. In the present study, the cell culture probably caused changes in the transcriptome of the endothelial cells; thereby, clues to pathophysiological dysfunction of endothelial cell transcriptomes in the acute phase of vessel occlusion may have been lost. Sun et al. demonstrated that they were able to directly perform qPCR on ECs harvested by inserting a curved stainless steel guide wire into the iliac artery in patients undergoing routine catheter angiography [21]. We were not able to reproduce this strategy in this model of MT in small arteries since our attempts to take the cells directly from MT to FACS and scRNA-seq failed. A possible reason for this could be compromised cell viability due to thrombus effect on the endothelial cells or by the relatively "dirty" cell mix that is obtained in the setting of MT. Complete manual removal of the thrombus from the stent retriever before EC dissociation, as described in the human setting by Sheth et al. [16], could possibly resolve this issue.

The limited numbers of the collected ECs in the setting of MT currently seem to limit materials for molecular analysis such as single-cell mRNA transcriptomics on freshly obtained cells. The intermediate step of cell culture to expand the ECs for transcriptomic analysis implies that the protocol in its current form is best suitable for studying chronic comorbidities, such as diabetes mellitus or hypertension, associated with ischemic stroke. Furthermore, the approach also shows the feasibility of creating an EC-in-AIS biobank.

Single-cell mRNA sequencing has emerged as a powerful method to simultaneously measure cell-to-cell expression variability of thousands of genes [22], and such analysis is possible with large amount of input cells. Sun et al. collected peripheral ECs, sorted them using FACS, 

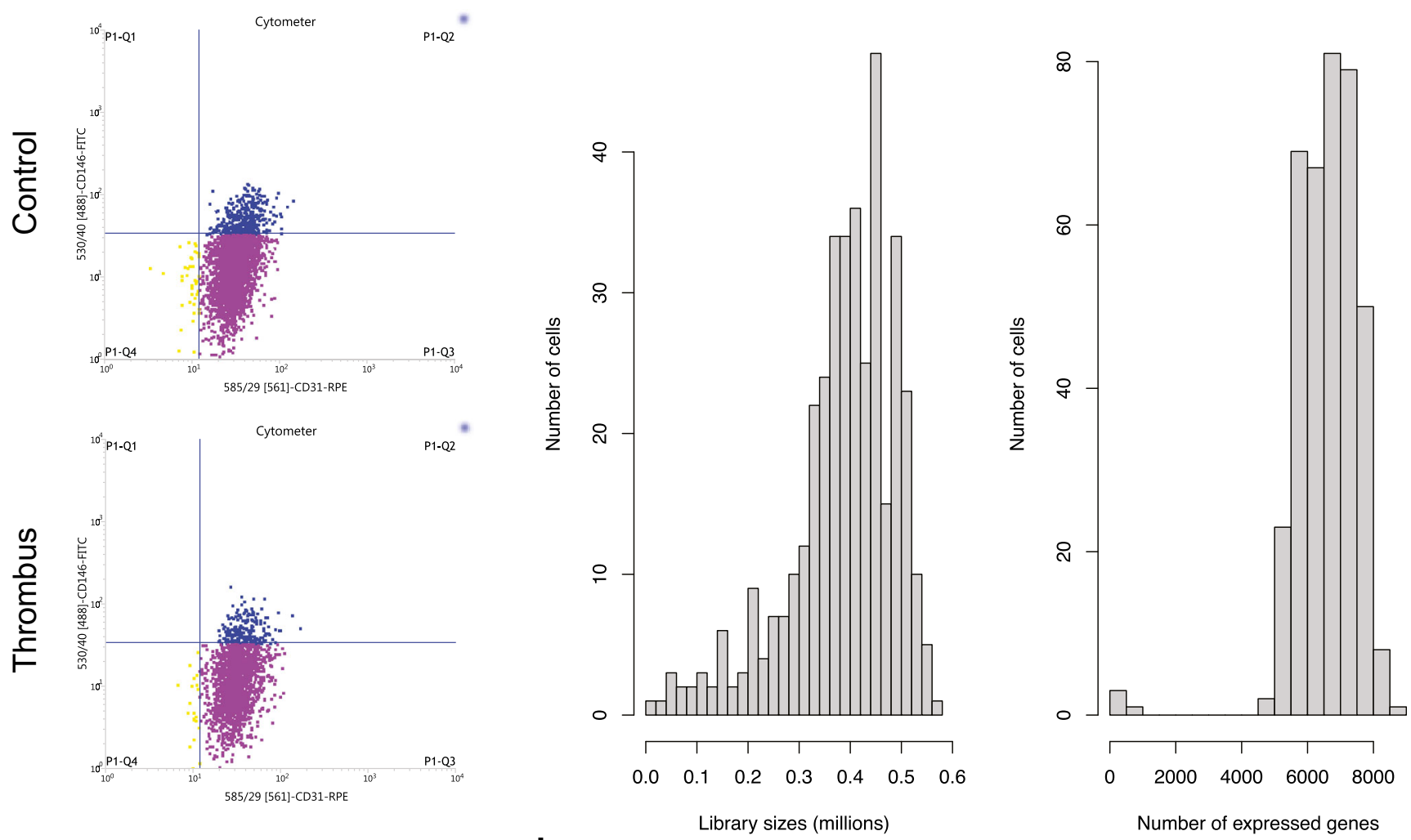

a

b

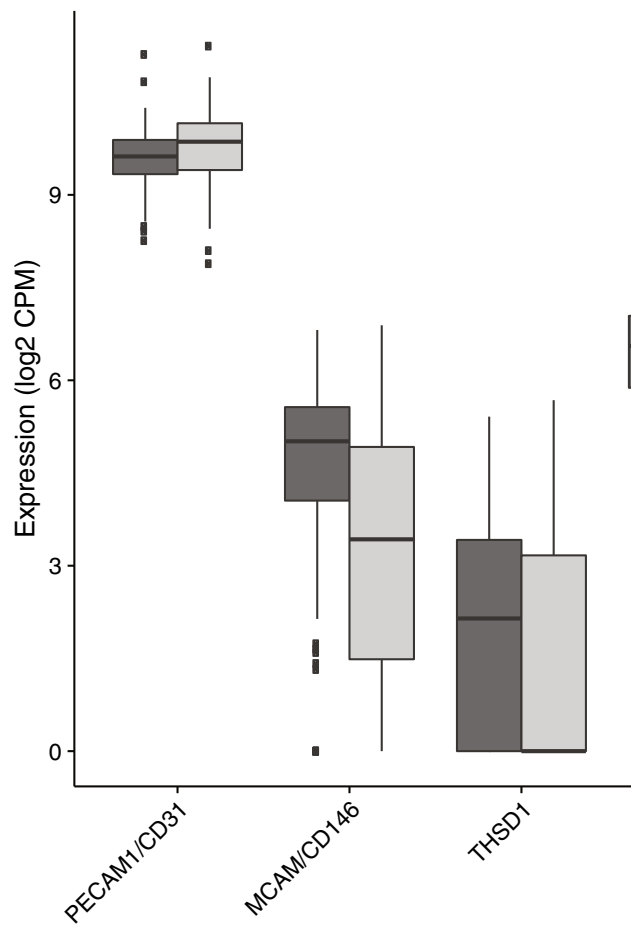

C

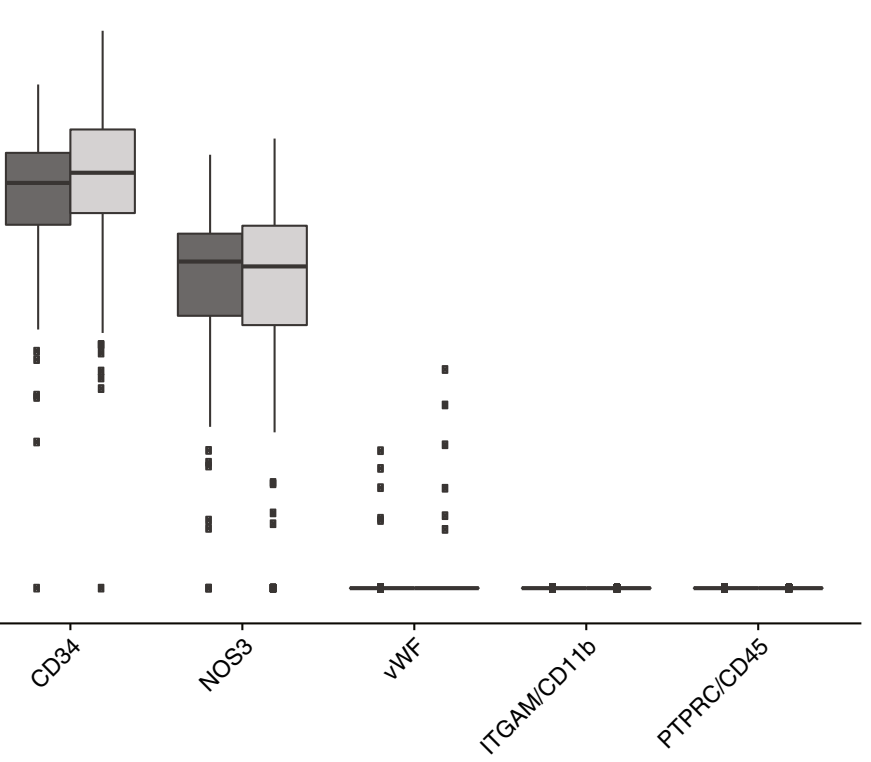

Group

官 control

追 thrombus

Gene

Fig. 3 a FACS final gates for EC cell sorting. CD31+ and CD146+ ECs were sorted for single-cell RNA sequencing. $\mathbf{b}$ Histograms of counts and number of expressed genes over all cells. c Expression of gene characteristics of endothelial cells in thrombus and nonthrombus

and analyzed single-cell gene expression. While Sun et al. yielded good results using quantitative RT-PCR on samples as well as genes that used as a negative controls (CD-11b and CD-45). Differential expression assessed by DESeq2, showing no significant difference between selected genes with a cutoff of absolute $\log _{2}$ fold change $\geq 1(p>0.05)$

high-throughput microfluidic platform [21, 23, 24], there is an inherent limitation in the scope of analysis that can 
be performed on data obtained using specific primers in RT-PCR in comparison to scRNA-seq. scRNA-seq offers considerably more expression information and is amenable to exploratory data analysis and hypothesis generation, to elucidate the role of ECs in neurovascular pathology.

An important possibility in transcriptomic analysis is the identification of subtypes within an input cell type, in this case ECs. When looking at differential expression of EC markers (positive and negative markers) in the thrombus compared to the control sample, none of the genes showed significant difference, suggesting a similar expression pattern between groups in regard to EC markers. Initial analysis showed some apparent clustering on PCA hierarchical clustering and heatmap analysis of highly variable genes (not shown). We considered cell cycle state as a source of bias in this case, as this was not controlled for in the sorting stage. Furthermore, the genes with large biological variance are almost exclusively genes that are associated with cell cycle-dependent variability. Therefore, we used a data processing method, ccRemover [19], to identify and remove principal components likely caused by cell cycle variation among the cells. Subsequent PCA and heatmaps did not show apparent clustering either within or between samples. If there are indeed phenotypical subtypes of ECs in the swine ECA, these phenotypes were not apparent in our sample after cell culture.
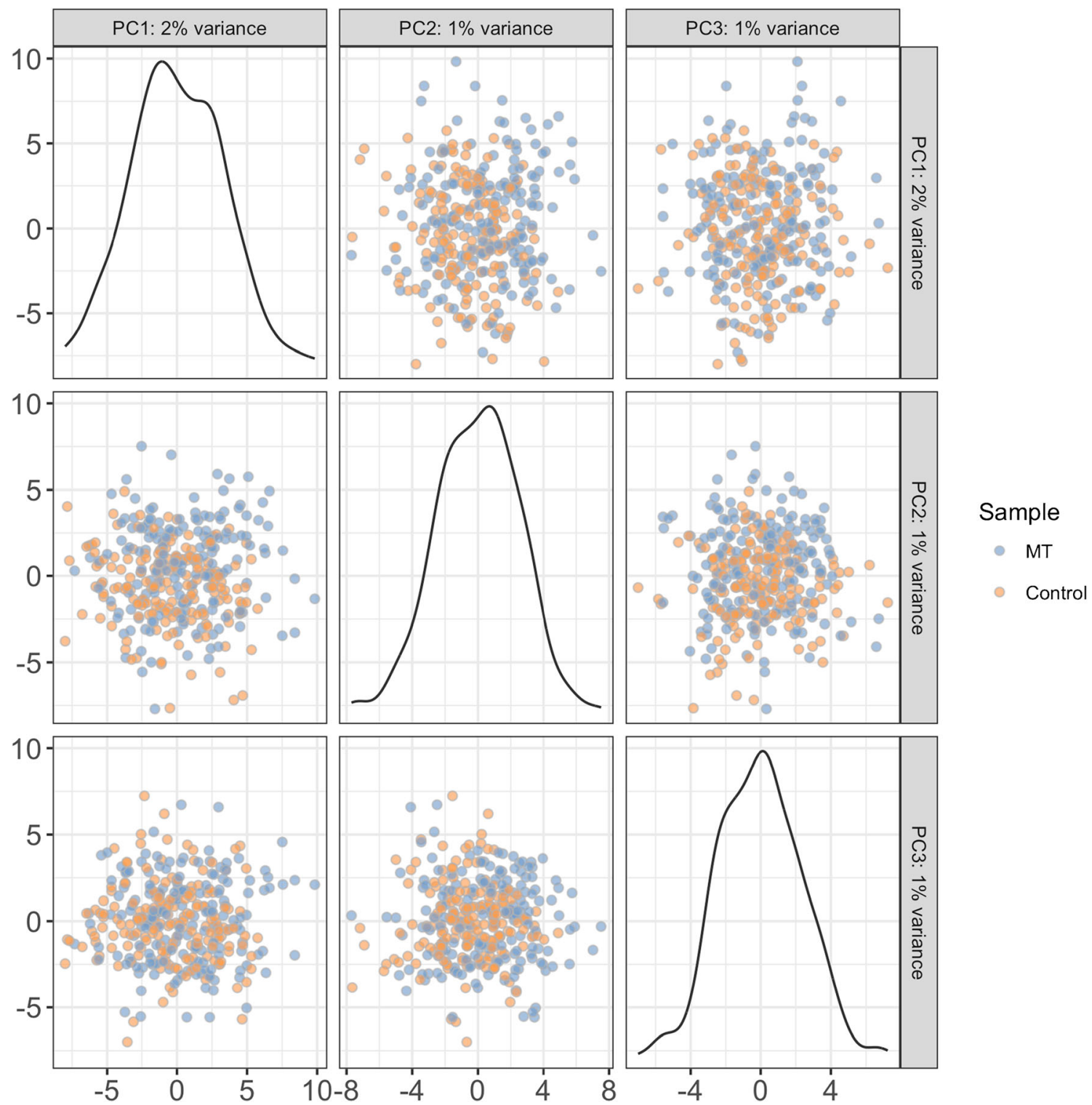

Fig. 4 a Principal component analyses (PCA) plot, showing the first 3 PCA components 


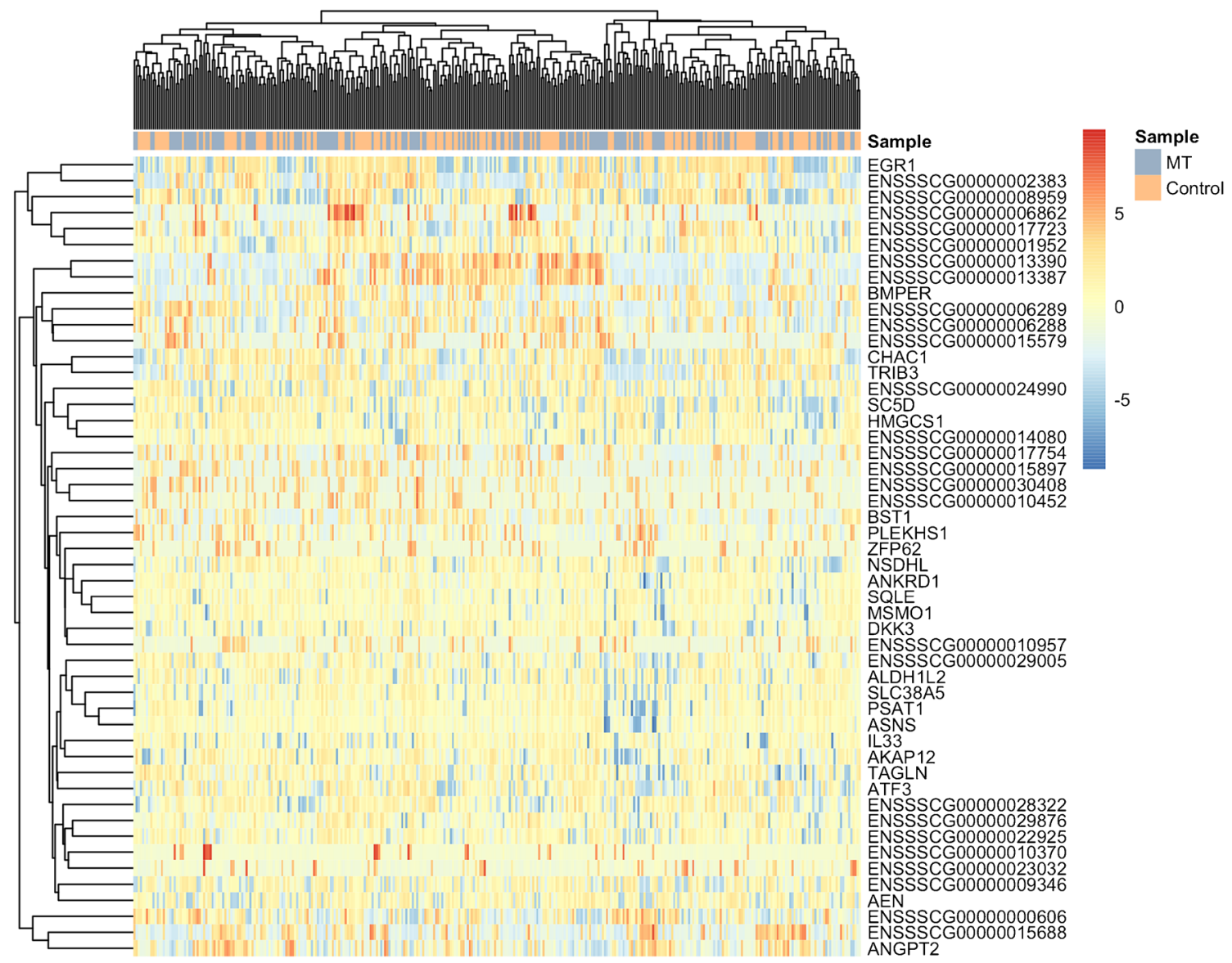

Fig. 5 Heatmap for the 50 high variable genes (HVG). Rows are genes; columns are cells. Clustering is done based on Euclidean distance. No clear clustering of cells within or between mechanical thrombectomy (MT) and control is seen

\section{Conclusions}

Evaluation of intracranial vascular endothelial dysfunction in patients undergoing ischemic stroke or other endovascular diseases has been limited so far. In this study, we present a pipeline for harvesting, culturing, and then analyzing endothelial cells using FACS and scRNA-seq in a model of mechanical thrombectomy. This pipeline for analysis could readily be integrated with the method of EC harvest in human AIS recently reported by Sheth et al. [16]. The time of the procedure is not extended, and the device itself is not affected by the harvesting method. This method allows systematic population of a biobank of human brain endothelial cell transcriptomes from patients undergoing ischemic stroke, providing a wealth of new research material to investigate the cellular and molecular mechanisms by which the vascular endothelium mediates the processes of physiology and pathophysiology of stroke and associated comorbidities.
Acknowledgements We thank Ulrika Nilsson and Pellina Janson for excellent technical assistance in the angio lab and with animal care. We thank Jaromir Mikes at the Mass Cytometry facility and Karolina Wallenborg and Simone Picelli at the Eukaryotic Single Cell Genomics Facility at the Science for Life laboratory for assistance with FACS and single-cell RNA seq. We thank the UPPMAX facility at Uppsala University and the BILS bioinformatics facility for assistance with scRNA-seq data processing and analysis.

\section{Compliance with ethical standards}

Funding This study was funded by the Söderberg Foundations, Familjen Erling Perssons stiftelse, Karolinska Institutet and Karolinska University Hospital.

Conflict of interest The authors declare that they have no conflict of interest.

Ethical approval All applicable international, national, and/or institutional guidelines for the care and use of animals were followed in accordance with the Karolinska Institute guidelines for experiments on large animals and were approved by the ethics committee (Norra Stockholms Djurförsöksetiska nämnd, dnr N87/15 and N162/16). 
Informed consent This article does not contain any studies with human participants performed by any of the authors.

Open Access This article is distributed under the terms of the Creative Commons Attribution 4.0 International License (http:// creativecommons.org/licenses/by/4.0/), which permits unrestricted use, distribution, and reproduction in any medium, provided you give appropriate credit to the original author(s) and the source, provide a link to the Creative Commons license, and indicate if changes were made.

\section{References}

1. Sumpio BE, Riley JT, Dardik A (2002) Cells in focus: endothelial cell. Int J Biochem Cell Biol 34(12):1508-1512

2. Corretti MC, Anderson TJ, Benjamin EJ, Celermajer D, Charbonneau F, Creager MA, Deanfield J, Drexler H, GerhardHerman M, Herrington D, Vallance P, Vita J, Vogel R, International Brachial Artery Reactivity Task F (2002) Guidelines for the ultrasound assessment of endothelial-dependent flow-mediated vasodilation of the brachial artery: a report of the International Brachial Artery Reactivity Task Force. J Am Coll Cardiol 39(2): 257-265

3. Mullen MJ, Clarkson P, Donald AE, Thomson H, Thorne SA, Powe AJ, Furuno T, Bull T, Deanfield JE (1998) Effect of enalapril on endothelial function in young insulin-dependent diabetic patients: a randomized, double-blind study. J Am Coll Cardiol 31(6):1330-1335

4. Thorne S, Mullen MJ, Clarkson P, Donald AE, Deanfield JE (1998) Early endothelial dysfunction in adults at risk from atherosclerosis: different responses to L-arginine. J Am Coll Cardiol 32(1):110-116

5. Ludmer PL, Selwyn AP, Shook TL, Wayne RR, Mudge GH, Alexander RW, Ganz P (1986) Paradoxical vasoconstriction induced by acetylcholine in atherosclerotic coronary arteries. N Eng1 J Med 315(17):1046-1051. https://doi.org/10.1056/ NEJM198610233151702

6. Li J, Zhao SP, Li XP, Zhuo QC, Gao M, Lu SK (1997) Noninvasive detection of endothelial dysfunction in patients with essential hypertension. Int J Cardiol 61(2):165-169

7. Widlansky ME, Gokce N, Keaney JF Jr, Vita JA (2003) The clinical implications of endothelial dysfunction. J Am Coll Cardiol 42(7): $1149-1160$

8. Berkhemer OA, Fransen PS, Beumer D, van den Berg LA, Lingsma HF, Yoo AJ, Schonewille WJ, Vos JA, Nederkoorn PJ, Wermer MJ, van Walderveen MA, Staals J, Hofmeijer J, van Oostayen JA, Lycklama a Nijeholt GJ, Boiten J, Brouwer PA, Emmer BJ, de Bruijn SF, van Dijk LC, Kappelle LJ, Lo RH, van Dijk EJ, de Vries J, de Kort PL, van Rooij WJ, van den Berg JS, van Hasselt BA, Aerden LA, Dallinga RJ, Visser MC, Bot JC, Vroomen PC, Eshghi O, Schreuder TH, Heijboer RJ, Keizer K, Tielbeek AV, den Hertog HM, Gerrits DG, van den Berg-Vos RM, Karas GB, Steyerberg EW, Flach HZ, Marquering HA, Sprengers ME, Jenniskens SF, Beenen LF, van den Berg R, Koudstaal PJ, van Zwam WH, Roos YB, van der Lugt A, van Oostenbrugge RJ, Majoie CB, Dippel DW, Investigators MC (2015) A randomized trial of intraarterial treatment for acute ischemic stroke. N Engl $\mathrm{J}$ Med 372(1):11-20. https://doi.org/10.1056/NEJMoa1411587

9. Goyal M, Demchuk AM, Menon BK, Eesa M, Rempel JL, Thornton J, Roy D, Jovin TG, Willinsky RA, Sapkota BL, Dowlatshahi D, Frei DF, Kamal NR, Montanera WJ, Poppe AY, Ryckborst KJ, Silver FL, Shuaib A, Tampieri D, Williams D, Bang OY, Baxter BW, Burns PA, Choe H, Heo JH, Holmstedt CA, Jankowitz B, Kelly M, Linares G, Mandzia JL, Shankar J, Sohn SI, Swartz RH, Barber PA, Coutts SB, Smith EE, Morrish WF, Weill A, Subramaniam S, Mitha AP, Wong
JH, Lowerison MW, Sajobi TT, Hill MD, Investigators ET (2015) Randomized assessment of rapid endovascular treatment of ischemic stroke. N Engl J Med 372(11):1019-1030. https://doi.org/10.1056/ NEJMoa1414905

10. Campbell BC, Mitchell PJ, Kleinig TJ, Dewey HM, Churilov L, Yassi N, Yan B, Dowling RJ, Parsons MW, Oxley TJ, Wu TY, Brooks M, Simpson MA, Miteff F, Levi CR, Krause M, Harrington TJ, Faulder KC, Steinfort BS, Priglinger M, Ang T, Scroop R, Barber PA, McGuinness B, Wijeratne T, Phan TG, Chong W, Chandra RV, Bladin CF, Badve M, Rice H, de Villiers L, Ma H, Desmond PM, Donnan GA, Davis SM, Investigators E-I (2015) Endovascular therapy for ischemic stroke with perfusionimaging selection. N Engl J Med 372(11):1009-1018. https://doi. org/10.1056/NEJMoa1414792

11. Saver JL, Goyal M, Bonafe A, Diener HC, Levy EI, Pereira VM, Albers GW, Cognard C, Cohen DJ, Hacke W, Jansen O, Jovin TG, Mattle HP, Nogueira RG, Siddiqui AH, Yavagal DR, Baxter BW, Devlin TG, Lopes DK, Reddy VK, Mesnil DU, de Rochemont R, Singer OC, Jahan R, Investigators SP (2015) Stent-retriever thrombectomy after intravenous t-PA vs. t-PA alone in stroke. $\mathrm{N}$ Engl J Med 372(24):2285-2295. https://doi.org/10.1056/ NEJMoa1415061

12. Jovin TG, Chamorro A, Cobo E, de Miquel MA, Molina CA, Rovira A, San Roman L, Serena J, Abilleira S, Ribo M, Millan M, Urra X, Cardona P, Lopez-Cancio E, Tomasello A, Castano C, Blasco J, Aja L, Dorado L, Quesada H, Rubiera M, Hernandez-Perez M, Goyal M, Demchuk AM, von Kummer R, Gallofre M, Davalos A, Investigators RT (2015) Thrombectomy within 8 hours after symptom onset in ischemic stroke. N Engl J Med 372(24): 2296-2306. https://doi.org/10.1056/NEJMoa1503780

13. Marder VJ, Chute DJ, Starkman S, Abolian AM, Kidwell C, Liebeskind D, Ovbiagele B, Vinuela F, Duckwiler G, Jahan R, Vespa PM, Selco S, Rajajee V, Kim D, Sanossian N, Saver JL (2006) Analysis of thrombi retrieved from cerebral arteries of patients with acute ischemic stroke. Stroke 37(8):2086-2093. https:// doi.org/10.1161/01.STR.0000230307.03438.94

14. Dobrocky T, Piechowiak E, Cianfoni A, Zibold F, Roccatagliata L, Mosimann P, Jung S, Fischer U, Mordasini P, Gralla J (2017) Thrombectomy of calcified emboli in stroke. Does histology of thrombi influence the effectiveness of thrombectomy? J Neurointerv Surg 10:345-350. https://doi.org/10.1136/ neurintsurg-2017-013226

15. Gounis MJ, Chapot R (2017) Histological composition and the origin of the thrombus: a new diagnostic assay for secondary stroke prevention? Stroke 48(8):2040-2041. https://doi.org/10.1161/ STROKEAHA.117.017630

16. Sheth SA, Verma A, Malhotra K, Tang X, Tateshima S, Jahan R, Hinman JD (2017) Human endothelial cell collection from the middle cerebral artery in acute ischemic stroke. J Stroke Cerebrovasc Dis 27:669-672. https://doi.org/10.1016/j.jstrokecerebrovasdis. 2017.09.054

17. Picelli S, Faridani OR, Bjorklund AK, Winberg G, Sagasser S, Sandberg R (2014) Full-length RNA-seq from single cells using Smart-seq2. Nat Protoc 9(1):171-181. https://doi.org/10.1038/ nprot.2014.006

18. Lun AT, McCarthy DJ, Marioni JC (2016) A step-by-step workflow for low-level analysis of single-cell RNA-seq data with Bioconductor. F1000Res 5:2122. https://doi.org/10.12688/ f1000research.9501.2

19. Barron M, Li J (2016) Identifying and removing the cell-cycle effect from single-cell RNA-sequencing data. Sci Rep 6:33892. https://doi.org/10.1038/srep33892 
20. Onat D, Brillon D, Colombo PC, Schmidt AM (2011) Human vascular endothelial cells: a model system for studying vascular inflammation in diabetes and atherosclerosis. Curr Diab Rep 11(3): 193-202. https://doi.org/10.1007/s11892-011-0182-2

21. Sun Z, Lawson DA, Sinclair E, Wang CY, Lai MD, Hetts SW, Higashida RT, Dowd CF, Halbach VV, Werb Z, Su H, Cooke DL (2015) Endovascular biopsy: strategy for analyzing gene expression profiles of individual endothelial cells obtained from human vessels. Biotechnol Rep (Amst) 7:157-165. https://doi.org/10. 1016/j.btre.2015.07.001

22. Shapiro E, Biezuner T, Linnarsson S (2013) Single-cell sequencingbased technologies will revolutionize whole-organism science. Nat Rev Genet 14(9):618-630. https://doi.org/10.1038/nrg3542
23. Sun Z, Su H, Long B, Sinclair E, Hetts SW, Higashida RT, Dowd CF, Halbach VV, Cooke DL (2014) Endothelial cell highenrichment from endovascular biopsy sample by laser capture microdissection and fluorescence activated cell sorting. J Biotechnol 192(Pt A):34-39. https://doi.org/10.1016/j.jbiotec.2014.07.434

24. Cooke DL, McCoy DB, Halbach VV, Hetts SW, Amans MR, Dowd CF, Higashida RT, Lawson D, Nelson J, Wang CY, Kim H, Werb Z, McCulloch C, Hashimoto T, Su H, Sun Z (2018) Endovascular biopsy: in vivo cerebral aneurysm endothelial cell sampling and gene expression analysis. Transl Stroke Res 9(1):20-33. https:// doi.org/10.1007/s12975-017-0560-4 